\title{
Stateless Citizenship and the Palestinian-Arabs in Israel
}

\author{
Shourideh C. Molavi
}

\section{Abstract}

This paper will focus on Israel's system of government with specific attention to the idea of citizenship and to its Palestinian-Arab citizenry. It will begin with a historical and political background of Palestinian-Arab citizens, along with an examination of their paradoxical circumstances living as non-Jewish citizens in a "Jewish state." The multi-faceted discrimination faced by PalestinianArab citizens is laid out in an attempt to outline the apartheid state structure and system that constitutes the Israeli regime. The ethnicized nature and structure of Israeli citizenship will then be explained, and an analysis of the limited access of Palestinian-Arabs to Israeli citizenship through an illustration of the state's legal definition and political characterization as a "Jewish state" will follow. This paper will argue that Israel's (hardening) ethnic policies and practices, coupled with internal Palestinian political rifts and resistance, have resulted in a notable shrinking space of citizenship. Expanding on this analysis of Israeli citizenship and state structure, this paper will introduce the concept of statelessness and argue that selfidentification of the Israeli state as "Jewish" repudiates the citizenship of the Palestinian-Arab community, rendering this collective stateless. The paradoxical status of statelesscitizenship will be explored to illustrate that this form of statelessness is not rooted in the absence of citizenship but rather in its presence, thus distinguishing between the statelessness of the Arab citizenry of Israel and the rest of the Palestinian nation. The paper will end with the application of Mark Salter's metaphor of the border, arguing that, as stateless-citizens, Palestinian-Arabs are in a permanent state of border exception, the effect of which makes their bodies into borders.

\section{Résumé}

Le présent article approfondit le système de gouvernement de l'État d'Israël en insistant particulièrement sur la notion de citoyenneté ainsi que sur ses citoyens arabo-palestiniens. L'auteure situe d'abord le contexte historique et politique des citoyens arabo-palestiniens et examine ensuite leur situation paradoxale de citoyens non juifs dans un "État juif». La discrimination à multiples facettes à laquelle sont confrontés les citoyens arabo-palestiniens est exposée dans un essai de définition du système et de la structure étatique d'apartheid que constitue le régime israélien. La nature et la structure ethnicisées de la citoyenneté israélienne sont alors expliquées, suivi d'une analyse de l'accès limité des citoyens arabo-palestiniens à la citoyenneté israélienne à travers une illustration de la définition juridique et de la caractérisation politique de l'État comme "État juif». L'auteure fait valoir que les politiques et pratiques ethniques (durcissantes) d'Israël, ainsi que la résistance et les clivages politiques internes palestiniens, ont entraîné une diminution notable de l'espace de la citoyenneté. En creusant davantage cette analyse de la citoyenneté israélienne et de la structure de l'État, l'auteure présente le concept de l'apatridie et affirme que l'auto-identification de l'État d'Israël comme «juif» répudie la citoyenneté de la communauté arabo-palestinienne, la rendant apatride. Le statut paradoxal de la citoyenneté apatride est étudié afin d'illustrer le fait que cette forme d'apatridie n'est pas enracinée en une absence de citoyenneté, mais plutôt en sa présence, discernant ainsi entre l'apatridie des citoyens arabes d'Israël et celle du reste de la nation palestinienne. L'auteure termine par l'application de la métaphore de la frontière de Mark Salter, faisant valoir que, en tant que citoyens apatrides, les Arabo-Palestiniens sont dans un état permanent d'exception des frontières, leurs corps étant euxmêmes des frontières. 


\section{The Forgotten Palestinians}

The nation-state framework is predicated on citizenship as the principle organizing relation between the state and its constituents, or citizens. As an institution, citizenship is comprised of the social community and implies that access to public goods and services, as well as participation in state institutions, exhibits the political civil and social rights of this collective. Indeed, citizenship has emerged as an issue which is central, not only to practical political notions concerning access to health-care systems, educational institutions, public programs, and the welfare state, but also to concepts of legal jurisdiction and social membership. Within the context of multi-ethnic state systems, practices accommodating the political and social dominance of one group with the concept of democratic citizenship can be identified. Through an analysis of these practices the dynamics of the citizenship available to minority or marginalized communities within a state system surfaces, illustrating the centrality of the specific social and political context in determining the realization of citizenship rights.

In the case of Israel, Zionism has largely been a territorial and demographic success. History has nearly forgotten the 156,000 Palestinian-Arabs ${ }^{1}$ who in 1948 remained in the areas of historic Palestine now called Israel, and were granted Israeli citizenship. The long history of the Palestinian-Arab citizens of Israel was shaped by the events leading up to the $1948 \mathrm{Nakba}$, or catastrophe, the result of which shattered and forcefully separated a community of approximately 950,000 people. ${ }^{2}$ The vast majority of these people either were forced from their land or fled under the duress of war to neighbouring Arab countries where they and their descendants have become the world's largest and oldest refugee population.

During the Nakba, Zionist forces expelled Palestinians from approximately 512 villages, from which village property such as houses, churches, mosques, grazing fields, cemeteries, orchards, cattle, and other properties were confiscated by the Zionist forces and either distributed among neighbouring Jewish settlements or withheld for the use of new Jewish settlements. ${ }^{3}$ With the Declaration of the state of Israel as a simultaneously Jewish and democratic state in $1948,{ }^{4}$ a policy of spatial Judaization was implemented by the Zionist political and military forces aimed at the establishment of a demographic balance in favour of the Jewish population through mechanisms of "regional" and "urban planning." This policy is fulfilled with a dual and simultaneous practice of developing and scattering exclusively Jewish settlements on (and immediately around) areas mainly inhabited by Arabs, while limiting and trumping the demographic, geographic, and socio-economic growth of Palestinian villages. While terms such as "spatial
Judaization" have almost disappeared from the current discourse of urban planning in Israel, the policies remain unchanged and are today replaced by expressions such as "attracting populations." 5

Israeli society is composed of two main national collectives, Jews and Palestinian-Arabs. The Palestinian people are a mainly Arabic-speaking collective with historical and familial origins in historic Palestine. Today one out of five citizens in Israel are Palestinian-Arabs, who number more than one million citizens and constitute 20.2 per cent of Israel's total population. ${ }^{6}$ While the Palestinians who remained within the boundaries of the new Israeli state were granted Israeli citizenship, they were also placed in a systematically dependent and inferior economic, political, and legal position. ${ }^{7}$ Indeed, rather than pursuing either elimination or integration/absorption of the PalestinianArab community, the Israeli policy has, from the beginning, been shaped by the objective of effective control. ${ }^{8}$

\section{Multi-faceted Discrimination in an Apartheid Regime}

Discrimination against non-Jewish citizens pervades every level of Israeli society, from the private to the public sphere, and at social, legal, and political levels. According to As'ad Ghanem, the channelling of rights through Israel's policy of Jewish dominance can be analyzed at three different levels: the declarative level, the structural level, and the operational level. At the formal and declarative levels, the preference of Jews over others is both tangible and indisputable. Visible symbols such as "official state holidays, state symbols and the flag, imposed religious observance, regulated dietary laws, and the legally enshrined definition of the state as the state of the Jewish people" are all built upon the premise of the social and political dominance of Jewish people and completely dismissive of the Palestinian citizenry. ${ }^{9}$ Indeed, although Arabic is also an officially recognized language, the Hebrew language is dominant in all spheres of Israeli society and while several laws are implemented to promote and preserve Jewish culture and create Jewish cultural institutions, such as The High Institution for Hebrew Language Law (1973) among others, no law exists which refers to Palestinian-Arab culture, history, or heritage. As a result, while Jews are provided legally enshrined rights both as a collective and as individual citizens, Arab citizens of Israel lack a clear and official legal and formal status in Israel as a collective, and fail to identify with the intrinsically Jewish and Zionist symbols of the state at an individual level.

At the structural level, Arab citizens of Israel are involuntarily excluded from Israeli institutions through various methods. To begin with, Arabs are excluded from the political decision-making centres. The Arab parties which are 
anti-Zionist or non-Zionist have historically played the role of a "permanent opposition" and have systematically been excluded from the important Knesset committees, such as Finance and Foreign Affairs, and Defence. ${ }^{10}$ Further, Arabs are systematically denied employment in senior positions, and are excluded from the centres of public, social, economic, and military power. Instead, special institutions have been created and assigned the task of dealing with Arab affairs and policy-making. Ghanem notes, "Frequently, these committees view the Arabs through a security lens and concentrate on the potential security risk allegedly correlated with ethnic considerations." ${ }^{11}$ For instance, Abeer Baker, lawyer with Adalah: The Legal Center for Arab Minority Rights in Israel points out that when it comes to the treatment of Palestinian citizens in political prisons, Israeli prison authorities consider Arab political prisoners as security prisoners. ${ }^{12}$ This classification determines a prisoner's treatment by the Israeli Prison Services including the prison to which she/he is assigned, the prison wing where she/he will serve the sentence, the provision of a leave, guarded home visits, and access to telephone calls from prison. Distinguishing between criminal and security prisoners was sanctioned by the Israeli Supreme Court, and while it is claimed to be applied to both Jewish and Arab prisoners, Baker argues that in practice it is only Palestinian prisoners who suffer the devastating ramifications of being declared security prisoners, as Jews imprisoned or detained due to attacks on Arabs for ideological reasons continue to benefit from the rights provided to criminal prisoners, even if they are officially classified as security prisoners. Consequently, prisoners who are Palestinian citizens of Israel continue to find themselves on a "double periphery." Palestinian political prisoners who are Israeli citizens are discriminated against as compared to Jewish prisoners in the harsher sentences they receive, and in the difficult prison conditions they are subjected to. At the same time, Palestinian citizens who are incarcerated are excluded from Israeli-Palestinian prisonerrelease agreements and from candidacy for early release as their situation is considered as an internal Israeli issue-a product of the Oslo Accords.

Finally, at the operative level, Palestinian citizens of Israel are denied equality in the realms of budgets, land allocations, and legislation. As equality among citizens is not legally entrenched, the Israeli legal system is able to emphasize the Jewish and Zionist character of the state. Further, the World Zionist Organization - Jewish Agency Law of 1952 guarantees that major Jewish and Zionist organizations are granted special status as quasi-governmental bodies. These organizations manage land, housing, and service provision, almost exclusively serving the Jewish population. As no non-Jewish organizations are granted similar status this state practice produces a remarkably lower quality of life for those who are Palestinian-Arab by denying them access to basic de facto citizenship rights.

Budgetary discrimination against the Arab community fuels the unequal allocation of resources to Arab and Jewish local authorities, furthering the laggard economic development of the Arabs in Israel. ${ }^{13}$ In the education sector, Palestinian-Arabs are refused the right to establish educational objectives and directions, subjected to discriminatory allocation of state funding and educational resources, and severely under-represented in the decision- and policymaking positions in the Israeli Ministry of Education. The Israeli education system is based on the State Education Law (1953). Amended in February 2000, this law sets educational objectives for state schools that emphasize Jewish history and culture. Stated in Article 2 of the law, the education system seeks primarily to advance the understanding of Zionist ideology and preserve the Jewish nature of the state by teaching its history, culture, and language. As a result, Arab state-run schools are faced with a discriminatory curriculum which allots more time to learning the Torah and other Jewish and Zionist texts than it does to studying the Qur'an, the New Testament, or literature produced by Arab scholars, and with inferior allocations for training, supervision, and structural, programmatic, and institutional development, resulting in poor infrastructure, limited instructors, and large numbers of students per classroom. ${ }^{14}$

When it comes to land allocation, Arabs face widespread discrimination in national and regional zoning plans. Ian Lustick has widely documented methods employed by the state to deprive Palestinians of their land by turning it into "state land managed by national and regional planning bodies."15 Lustick points out that in 1960, the Basic Law: Israel-Lands Law and Israel-Lands Administration Law were formulated on behalf of the Israeli government, deeming that the land controlled by the Jewish National Fund (JNF) would now be administered by a single authority, the Israel Land Administration (ILA). However, it was agreed that "the lands controlled by the ILA shall be administered according to the principles of the JNF," and its declared goal of "purchasing and developing land as a national resource of the Jewish people, by the Jewish people, and for the Jewish people." 16 As such, the ILA is forbidden from selling or leasing the land to non-Jews. This extraterritorialization of the land places it beyond the control of the government, rendering it inaccessible to all Israeli citizens. Thus, while, prior to 1948, members of the Palestinian-Arab community owned and/or cultivated some 93 to 94 per cent of the land in geographical Palestine, today, 93 per cent of the territory of Israel is under direct control of the state and administered under a land tenure system which continues 
to deny Palestinian-Arabs access in the form of leasing and cultivation.

At the legislative level, while the list of discriminatory laws is too long to list in this publication alone, there are a few which deserve special attention given their disproportionately devastating effect on the Palestinian-Arab community. As the most important legal expression of Israel's self-definition as a Jewish state, the Law of Return (1950) guarantees "automatic citizenship to any Jew upon immigration to Israel, without any length-of-residence or language requirement." 17 The Law of Return applies to any Jew looking to immigrate to Israel, to her/his spouse, children, grandchildren, and their respective spouses, and applies to Jewish immigrants after the establishment of Israel and retroactively to Jews who had immigrated to Palestine or had been born there before the creation of the state without preconditions. However, Palestinian refugees who were expelled from their land and homes in 1948 are not granted the Right of Return and not even entitled to residency or citizenship status. In essence, an ethno-nationalist citizenship is established through this legal tenet encompassing all Jews, and only Jews, by virtue of their ethnic descent. This law solidifies the secondary citizenship status of PalestinianArabs as there is no chance for a non-Jew to acquire citizenship through the Ministry of Interior, and even spouses of Palestinian-Arab citizens of Israel can only gain citizenship or residency status thorough complicated and exhausting legal procedures. ${ }^{18}$

Systematic and state-led discrimination at the declarative, structural, operational levels illustrates the range of services, rights, benefits, and opportunities denied to the Palestinian citizenry of Israel by virtue of their non-Jewish ethnic affiliation. Such a situation, combining both formally written or legal principles and informal political practices, was defined by Yasmin Soysal as an "incorporation regime."19 This, Soysal argues, refers to "patterns of institutional practices and more or less explicit cultural norms that define the membership of individuals and/or groups in the society and differentially allocate entitlements, obligations and domination." ${ }^{20}$ In other words, an incorporation regime is a regime of social, political, economic, and cultural institutions that stratify the assumed equal or universalist citizenship of the state through a differential dispensing of rights, benefits, and obligations to various communities.

An examination of Israel's formal and informal practices reveals that its incorporation regime is structured in the form of an apartheid state system, namely systematic discrimination that is legally and institutionally enshrined so as to maintain the domination of an "ethnic" or "racial" group over another. ${ }^{21}$ While historically and politically associated with the practices and policies of the South
African apartheid regime from 1948 to 1994, the definition of the crime of apartheid in the International Convention on the Suppression and Punishment of the Crime of Apartheid, adopted by the United National General Assembly in 1973, points out that the definition of the crime of apartheid was not limited to the case of South Africa. ${ }^{22}$ As Hazem Jamjoum points out, that apartheid is defined as a crime under the 2002 Rome Statute of the International Criminal Court, enforced long after the apartheid regime was defeated in South Africa, attests to the fact that apartheid is a system that can be practised by any state. ${ }^{23}$

Resulting from the apartheid structure of the Israeli legal and political regime is a dynamic where, in principle, Israel invites its Palestinian citizens to engage in public economic, political, cultural, and social life, but it does not offer equality. Instead, through apartheid policies and practices the state maintains Jewish superiority in all fields, actively elevating their symbolic, structural, and practical dominance. ${ }^{24}$ Israel permits its Palestinian-Arab citizens to exercise basic rights, including the right to vote for and be elected to legislative bodies, and the right to freedom of movement, organization, and expression, however limited. Yet, as mentioned, Israel simultaneously adopts apartheid policies of domination and control that guarantee continued Arab marginality in all social, political, and legal spheres, thus incorporating this community as citizens without citizenship rights. ${ }^{25}$

\section{Ethnicized State, Ethnicized Citizenship}

The nature of the state is often translated into the character of its citizenship. As a movement seeking out a territory for colonization and immigration, Zionist politics aimed at creating a homogeneous population of largely immigrants in Palestine. This Judaization project creates socio-political and legal conditions which foster pervasive discrimination against non-Jewish citizens and thus which challenge the tenets of democratic citizenship.

Citizenship often represents the intersection of law and identity, where both an affiliation to a national collective and a constitutionally recognized membership in a state are articulated. It is conventionally conceived of as a mechanism of civic incorporation within a state; a form of social membership used as a basis for claim-making with access to rights, privileges, and freedoms allocated and protected by state institutions. The concept of citizenship is comprised of various articulations of membership and its accompanying rights, each of which reflects an analysis of the particular ethnic relations within that state.

The discourses of citizenship central to our analysis are liberal, republican, and ethno-nationalist, as Israeli citizenship is comprised of an amalgamation of these three concepts of state membership. ${ }^{26}$ The liberal conception of 
citizenship emphasizes personal liberty, viewing "individuals, and only individuals, as the bearers of universal, equal and publicly affirmed rights." ${ }^{27}$ Individuals are said to be sovereign actors who pursue their personal advantage, and given the absence of a sense of obligation to the community, political interference by the state is limited to a "negative" form of engagement, namely, the protection of individuals from interference in their exercise of inalienable rights. In return for this protection, individuals are required to engage in minimal political duties, such as voting, paying taxes, adhering to legal stipulations, and, in the case of Israel, serving in the military. Hence, citizenship, in the liberal view, consists of a collection of rights aimed at protecting the individual from encroachment by other members of society, including the state, while legitimating the state's authority over individuals. ${ }^{28}$ However limited, this concept of citizenship is reflected in Israel in the ability of the state to tolerate religious, cultural, and political diversity by creating a political realm protecting individual rights and an institutional framework within which the expression of this diversity can develop. In other words, the existence of mosques and churches, and the range of organized political groups within Israel, however limited, denote traces of a liberal current within Israeli society.

The understanding of citizenship as acquired or realized through identification with and active participation in the political community is reflected in the concept of republican citizenship. Members of a republican community are required to experience, or should experience, their citizenship "not intermittently, as merely protective individual rights, but rather as active participation ... in a morally inspired life." 29 This concept is reflected in the Israeli case through requirements that Jewish citizens complete mandatory military service in the Israeli Defence Forces. This criterion entitles them to a preferential share of the society's resources such as low-interest bank loans, employment, free education, free public transportation, and more.

However, mandatory service is limited to the Jewish majority, which introduces the third and final dimension of citizenship, namely, an ethno-national membership. Ethnonational citizenship roots membership in a special kind of community, the nation or ethnic group, which in this case is Jewish. Israel's legal, political, and ideological self-definition as a "Jewish state" adopts an ethnicized understanding of citizenship that dominates the limited but existing liberal and republican currents in its society. Ethnicized Israeli citizenship is "not an expression of individual rights but of membership in a homogenous ethnic group." 30 This systematically denies access to the aforementioned social resources to non-Jews, or those outside this ethnicized collective. Indeed, while a small number of Druze and Arab-Christian recruits were recently allowed entry into the Israeli military, indicating republican tendencies in Israel's conception of citizenship, these individuals are denied access to the full range of privileges that come with military service which are otherwise provided to Jewish soldiers, further illustrating its ethno-national framework. ${ }^{31}$

An explanation of the ethnicized nature and structure of Israeli citizenship goes back to the beginning of the Zionist settlement project during the British Mandate of Palestine (hereafter Palestine) at the end of the nineteenth century. Israeli political theorist Baruch Kimmerling argues that Zionism, the nationalist movement that motivated the Jewish immigration and settlement in Palestine, developed from the historical matrix of "traditional global colonialism." ${ }^{32}$ Kimmerling points out, however, that Zionism was "sophisticated enough to distance itself" from traditional global colonialism through an emphasis on the "uniqueness of the Jewish problem: anti-Semitism, persecution, and later the Holocaust." 33 Presenting itself as the sole moral solution, the Jewish immigration movement was able to expound itself as a return to Zion to correct years of injustice against the Jewish people, thus disconnecting itself from European colonial movements in other continents. ${ }^{34}$ Indeed, since the establishment of a "Jewish state in Eretz-Israel" in 1948, a political culture emerged in Israel that may be analyzed as a pattern of interaction between the exclusionary aspects of its colonizing and nation-building practices, and the inclusionary dimensions of its state institutions. ${ }^{35}$

\section{A State for All of Its Jewish Citizens}

The understanding of citizenship adopted in this paper is not simply a collection of formal and legally enshrined rights. Rather, citizenship also involves the entire mode of incorporating individuals and collectives into the societal order. This highlights the role of specific state institutions in facilitating social inclusion and draws attention to the variety, range, and dynamics of this membership. Although citizenship is meant to confer rights to all of its memberswhose status is formulated against a non-member, or an other-access to those rights is not equal. Like other forms of inequality, access to citizenship rights should also be understood as resulting from an intersection of multiple axes of difference. To name a few, these axes include nationality, religion, gender, class, and legal status, are channelled through a variety of democratic state institutions, and operate to constrain and facilitate access to civic rights even in the presence of citizenship status. Through this arrangement of citizenship status and access to rights, it becomes evident that citizenship rights in Israel are channelled through sophisticated ethnicized policies of exclusion, allied with limited inclusion in all spheres of life. These policies fuel 
and are fuelled by the absence of a provision in Israeli law for the concept of constitutional equality. Equality is absent from The Basic Law, ${ }^{36}$ and while laws exist which protect the equal rights of disadvantaged groups such as women and the disabled, no general statute relates to the right to equality for all citizens. ${ }^{37}$

In fact, although the definition of the Israeli state is continually contested, movements within Israel to amend the wording of The Basic Law since 1985 so that the state of Israel is "the state of its citizens" or "the state of the Jewish people and its Arab Citizens" have consistently been voted down by Israeli Knesset members. ${ }^{38}$ Indeed, an examination of two controversial resolutions initiated in 2009 in the Knesset indicates that, rather than being a right, meaningful citizenship for a Palestinian-Arab is considered a constitutional privilege, conditional on the negation of her/his ethnic identity and claim to equal rights. The first is the Jewish and Democratic State Bill, which criminalizes any political expression which challenges the Jewish or Zionist nature of the state. ${ }^{39}$ With this legislation, efforts to secure equal legal and political status for Palestinian-Arabs by highlighting the discriminatory legal and political outcomes of Israel's total preference for its Jewish citizens are criminalized and rendered a maximum prison sentence of one year. An amendment to the Citizenship Law of 1952 is the second, and it requires anyone receiving Israeli citizenship by birth or naturalization, as well as any citizen or resident applying for a national identity card, to make the following pledge of loyalty:

I declare my allegiance to the state of Israel as a Jewish and Zionist state, to the principles of the declaration made upon establishment of the state of Israel, to the state's flag and its hymn. I promise to perform compulsory service or alternative service as specified by statute $^{40}$

This bill is discriminatory in two important ways: it authorizes the Minister of Interior to revoke the citizenship of Israeli citizens who do not complete military or alternative national service; thus serving as an attack against conscientious objectors refusing to partake in Israeli human rights violations against the Palestinian people, and it compels Palestinian Arabs to recognize the Jewish character of the state and swear loyalty to the values of Zionism.

This nexus of liberal and ethno-national currents in Israeli legal and political structures has sparked widespread debates among scholars attempting to define Israeli democracy. The debate in Israeli academia was initially dominated by two major approaches. The mainstream account pushed forward by Israeli thinkers such as Asher Arian and Yaron Ezrahi followed the outlook of the Israeli High Court of Justice and considered the state to be a liberal democracy, albeit with certain deficiencies. The second approach was advanced by scholars such as Sammy Smooha and Yoav Peled, who define Israel as an "ethnic democracy," discerning persistent and systematic inequalities between Arabs and Jews, particularly in the exercise of collective rights but also in the overall democratic framework guaranteeing basic civil rights. ${ }^{141}$ However, these approaches could not account for the structural divisions which reproduced the existing ethnic and religious inequalities. This led to the emergence of a third approach led by both Arab and Jewish scholars-and one whose conclusions are expanded on in this paper to apply the apartheid analysis to the Israeli state system-which includes Nadim Rouhana, As'ad Ghanem, and Oren Yiftachel, all of whom define Israel as an "ethnocracy ... ethnic state ... or imagined democracy." 42 These thinkers uncovered the range of structural impediments to Israel's consolidation as a stable liberal democratic state, highlighting the nature of Israel as "not only Jewish, but also a Judaizing regime with ongoing policies and practices of expanding and deepening Jewish control" over economic and territorial resources within the state. ${ }^{43}$

\section{From Citizens to "Stateless Citizens"}

Uneven allocation is legitimated through the way in which social membership is conceived and granted within the state. In the case of Israel, its status as a Jewish state is not only a source of identity but it is also the guarantor of Jewish-identity-based rights. This is because Jewish identity in Israel provides an entirely new set of rights irrespective of formal citizenship. In other words, Jewish identity within the state of Israel is automatically conflated with Israeli citizenship. Like other incorporation regimes, Israeli citizenship is composed of concentric circles within which the boundaries of civic status for the Palestinian community are distinctly rigid given their peripheral location. ${ }^{44}$ And so, this community is limited to a rigid citizenship located in the periphery, as any possibility for movement towards the centre requires a social mobility that is systematically denied to it by virtue of the self-definition of the stateand such rights-as Jewish. The fruition of social mobility requires more rights and greater access to resources, the denial of which reduces the prospects of any meaningful Arab citizenship.

For the most part, this is where the existing literature stops. The existing literature largely agrees that the most important factor in delineating the contours of the relationship between Israel and its Arab minority is the constitutionally enshrined ethnic exclusivity of the state. The self-definition of the "nation" as Jewish is deemed a significant determinant of the relationship between the state 
of Israel and its Palestinian citizenry, and is a response to more external developments, namely, the Israel-Palestine conflict. Citizenship rights are thus denied to Arab citizens of Israel through a multi-faceted system of institutional and social control, leaving them with mere citizenship status, or citizenship in the law. While these conclusions are accepted in this paper, an examination of the implications of the designation of this community as citizens gives rise to a larger paradox. The self-identification of the state as an essentially Jewish state, with a national Jewish identity, and a demographic caveat requiring a Jewish majority within the territories under Israeli control, complicates any political, national, identity, or membership ties between the state and the Arab citizenry. The constitutional self-definition of the state as Jewish-since it requires the adoption of structural and institutional policies of domination and control-repudiates the citizenship of the Arab community. In essence, the Palestinians in Israel become a paradox: stateless citizens. Thus, the challenge to Israel's consolidation as an equal democracy is not that citizenship rights were inadequate or unequal, but that access to citizenship itself, in the form of state identification or membership, is deliberately designed to exclude the non-Jewish community.

The Arabs in Israel are denied national-membership as non-Jews, and state-membership given Israel's legal, political, and social self-definition as a state for the Jewish people. At the same time, this community is also distanced from the rest of the Palestinian-Arab community through the same legal, political, social dimensions. As argued by Arendt, the only substitute for a home that is offered by a regime of nation-states is "an internment camp, a site of prolonged homelessness, an institutionalized limbo," or statelessness. ${ }^{45}$ What is unique in this case is that the statelessness of the Arabs in Israel is not in the absence of citizenship, but rather the presence of citizenship status. It is not the selfidentification of the state as belonging to a single, specific ethnic community with legal and institutional mechanisms in place to exclude all non-Jews from Israeli citizenship that excludes Palestinians. Paradoxically, it is their inclusion into what is essentially an exclusive legal and political state which fosters their exclusion from state membership. This paper begins where the existing literature ended, and conceptualized Arabs as citizens without citizenship rights. Yet an examination of the framework of Israeli citizenship within the definition of a Jewish state reveals that citizen status itself becomes repudiated or withdrawn as it does not include the Arab population within the state-citizen relationship. One witnesses the development of new form of citizenship stemming from the self-identification of the state as a Jewish state: stateless citizen status.

\section{Becoming the Borders of the "Jewish State"}

With this analysis, a familiar arrangement surfaces where, like all Palestinians, the Palestinians inside Israel too are rendered stateless. The differing element is that it is citizenship which serves as their entry into statelessness. It is important to note here that this paper does not seek to assert that the stateless Palestinian citizens of Israel are of equal political, legal, or socio-economic status as those stateless Palestinians in the West Bank, Gaza Strip, or refugee camps and legal limbo around the Arab and non-Arab world. However limited, there are significant privileges, such as mobility rights, granted to the Palestinian-Arab community through their inclusion in the discourse of rights as citizens of Israel which are vehemently denied to the rest of the Palestinian community. Rather, the statelessness of the Arabs in Israel outlined in this paper is most accurately reflected in Mark Salter's account of the experience of the "neurotic citizen at a border examination." ${ }^{36}$ Salter delineates an "embedded confessionary complex" faced by the citizen at the border which, rather than viewed as a "simple line indicating the limits of sovereign jurisdiction," is defined as "performative." ${ }^{77}$ Salter asserts that "border agents and state bureaucrats play a critical role in determining where, how, and on whose body a border will be performed," and with this verdict, these representatives establish the border as a permanent state of exception. ${ }^{48}$ Border examinations compel citizens to perform both their citizenship and the sovereignty of the state, placing them in an indefinite state of exception.

Salter's metaphor of the border is more reflective of the political and legal realities of the Palestinian citizens of Israel than Giorgio Agamben's conception of the camp. ${ }^{49}$ While Arabs citizens of Israel are not residing in actual refugee camps, they are in a permanent state of border exception, the effect of which makes their bodies into borders. Salter states, the "law is always at its limit at the border, because the decision of entrance to the territory and correspondent membership in the community is the equivalent to force." 50

The borders of the state of Israel are enacted on and through the bodies of Palestinian-Arabs as stateless citizens. While present in what is internationally recognized as the territory of the state because of their formal citizenship status, Palestinians inside Israel lack a solid relationship with and membership in either the Israeli "nation" or state given its self-definition as Jewish. As stated by Oren Yiftachel, because the state of Israel is "defined (non-territorially) as Jewish, and Arabs can never become Jewish, their right to citizenship is structurally (and indirectly also territorially) denied." ${ }^{1}$ Thus, Israel is a Jewish state and, as non-Jews, Arab citizens define the limits of the borders of 
the state. This dynamic becomes particularly interesting when one notes that Israel is the only internationally recognized state in the world without borders. ${ }^{52}$

The only ethic governing the border, and by extension the bodies of the Palestinian citizens of Israel, is what Salter calls the "Machiavellian 'virtue' of security ... a narrative of sovereign protection that obscures the running state of exception at the border." 53 Through the application of a security discourse, Israel has systematically denied its Arab citizenry access to social, political, and economic benefits including access to land, resources, and high-ranking political and legal state posts, among other benefits. Rather than serving as an exception to the fact, the security rhetoric directed at Palestinian citizens reflects a permanent amalgamation by the state of the physical and conceptual presence of this community with the notion of an existential threat. The actions of the state of Israel constantly merge the existence and inclusion of the Arab community within its boundaries with the notion of a "security threat." And so, as this decision is always made at the border according to Salter, the bodies of the Arabs in Israel effectively become the borders of the "nation" of Israel, and the state.

Through motions for equal citizenship and access to its associated rights Arab citizens are repeatedly asking for recognition from the state, but in doing so as non-Jews, they are simultaneously eroding its fundamental character as Jewish, thus posing an existential threat to the state. Reacting to these movements as measures of self-defense, the state of Israel establishes bureaucracies of admission and expulsion in an attempt to maintain its Judaized dominance and sovereign power, and in doing so, reinforces its borders upon and against the Palestinian community. Although there are significant differences between the political, military, and legal measures employed by Israel against Palestinians within its formally recognized borders and those in what is called the Occupied Palestinian Territories (OPT), namely the West Bank and Gaza Strip, the fundamental sovereign performance remains similar. That said, there are well-documented cases of the use of force against Palestinian citizens of Israel reminiscent of that launched against those in the OPT. For instance, in October 2000 (during the Second Intifada) the resentment of Palestinian-Arab citizens of Israel towards the state culminated in street demonstrations protesting both the illegal occupation of the Palestinian territories and the institutional discrimination of Israel's Arab citizenry. By the end of ten days of violence, thirteen PalestinianArab citizens were killed, and hundreds were injured by Israeli police or Israeli Jews. Over the course of the next few months, human rights organizations reported trends of arbitrary arrest and detention, as well as inhumane treatment of Arab citizens in custody, reflective of the exact measures faced by those in the OPT, thus highlighting the military, political, legal, and conceptual parallels between the Israel's treatment of its Palestinian citizens and those formally under occupation in the Palestinian territories.

Perhaps most reflective of the paradox lived by Palestinians with Israeli citizenship is Salter's contention of a citizen that is "always already and never fully inscribed as part of the population." ${ }^{4}$ As Israeli citizens they are uprooted as non-Jews, both in the conceptual and political sense, and simultaneously defined as a threatening other to the state. Palestinian refugees are enemies of the state both inside and outside its borders, as their existence reminds the sovereign of exceptions to membership in the nation-state framework and thus exceptions to its rule (and in the case of Israel, the refugee issue uproots its historical denial of ethnic cleansing campaigns during the course of its establishment). Palestinian stateless citizens of Israel instead become the border and are never realized as fully inside or outside the state.

The boundaries of Palestinian-Arab citizenship have been drawn to create a consciousness among Jews and Arabs alike that the citizenship of Palestinian-Arab is in certain respects not real or, at best, temporary. Indeed, a deconstruction of the Israeli incorporation regime and the ambiguous concept of a Jewish and democratic state is needed, and has been attempted by this paper, to provide an avenue for an inclusive political and legal status, encompassing a meaningful citizenship for Palestinian-Arabs. Such an initiative would erase the political and conceptual borders embedded in the bodies of the Arab citizenry and destabilize the paradoxical status of stateless citizenship.

\section{Notes}

1. Throughout this paper the terms "Palestinian-Arabs," "Palestinians," and "Arabs" will be used interchangeably to refer to the citizen collective within what is often called Israel proper (pre-1967 borders). This terminology is used to highlight that, while the Arab community has Israeli citizenship, they also have a shared history and collective experience with Palestinians in the West Bank, Gaza Strip, refugee camps and the disapora, and a shared language and culture with those in the broader Arab world.

2. Ian Lustick, Arabs in the Jewish State: Israel's Control of a National Minority (Austin: University of Texas Press, 1980), 28-29.

3. Salman Abu Sittah, Record of the Nakba (London: Palestinian Awdah Center, 1998).

4. The Jewish character of the state of Israel was first defined within the Declaration of Independence of 1948. The "democratic" character was first officially added to this in a 
1985 amendment to the Basic Law. See online: http://www. knesset.gov.il/laws/special/eng/basic2_eng.htm.

5. Ghazi Falah, "Israeli 'Judaization' Policy in Galilee," Journal of Palestine Studies 20, no. 4 (Summer 1991): 69.

6. "Israel at 61: Population stands at 7.4 million, $75.5 \%$ Jewish," Haaretz, online: http://www.haaretz.com/news/ israel-at-61-population-stands-at-7-4-million-75-5 -jewish-1.274935 (accessed 18 June 2010).

7. Gila Menahem, "Arab Citizens in an Israeli City: Action and Discourse in Public Programmes," Ethnic and Racial Studies 21, no.3 (1998): 546.

8. As'ad Ghanem, "State and Minority in Israel: The Case of the Ethnic State and the Predicament of Its Minority," Ethnic and Racial Studies 21, no. 2 (1998): 429.

9. Ibid., 440.

10. Ibid.

11. Lustick, 210.

12. Abeer Baker, "The Definition of Palestinian Prisoners in Israeli Prisons: 'Security Prisoners' - Security Semantics for Camouflaging Political Practice," Adalah's Review 5 (2009): 65-78.

13. Ghanem, "State and Minority in Israel," 432.

14. K. Abu-Asbeh, "Arab Education in Israel: Between the Discourse of Struggling Identity and Low Achievement," Adalah's Newspaper 63, online: http://www.adalah.org/ features/education/Arab_Education_in_Israel_English _for_Khaled_FINAL.pdf. (accessed 18 January 2010).

15. Lustick, 244.

16. Badil-Resource Centre for Palestinian Residency and Refugee Rights and Centre on Housing rights and Evictions (COHRE), Ruling Palestine: A History of the Legally Sanctioned Jewish-Israeli Seizure of Land and Housing in Palestine (Bethlehem: Badil, 2005).

17. Baruch Kimmerling, "Religion, Nationalism and Democracy in Israel," Constellations 6, no. 3 (1999): 342.

18. Ibid.

19. Gershon Shafir and Yoav Peled, Being Israeli: The Dynamics of Multiple Citizenship (Cambridge: Cambridge University Press, 2002), 45.

20. Yasmin Soysal, Limits of Citizenship, Migration and Post-National Citizenship in Europe (Chicago: Chicago University Press, 1994).

21. Karine Mac Allister, "Applicability of the Crime of Apartheid to Israel," Badil-Resource Centre for Palestinian Residency and Refugee Rights, al-Majdal 38 (Summer 2008), online: http://www.badil.org/al-majdal/2008/summer/articles02 .htm. (accessed 18 June 2010).

22. Ronald Bruce St John, "Apartheid by Any Other Name," Foreign Policy in Focus (February 1, 2007), online: http:// www.counterpunch.org/stjohn02022007.html. (accesssed 18 June 2010).

23. Hazem Jamjoum, "Not an Analogy: Israel and the Crime of Apartheid," Electronic Intifada, online:

http://electronicintifada.net/v2/article10440.shtml (accessed 18 May 2010).
24. Shourideh Molavi, Stateless Citizenship: The Case of the Palestinian Arabs in Israel (Chicago: Haymarket Books, forthcoming).

25. As'ad Ghanem, The Palestinian-Arab Minority in Israel, 1948-2000: A Political Study (New York: State University of New York Press, 2001), 431; Nimer Sultany, Citizens without Citizenship: Israel and the Palestinian Minority 20002002 (Mada al-Carmel: Arab Center for Applied Social Research, 2003).

26. Gershon Shafir and Yoav Peled, "Citizenship and Stratification in an Ethnic Democracy," Ethnic and Racial Studies 21, no. 3 (1998): 408-427.

27. Ibid., 411.

28. Ibid., 415 .

29. Ibid., 417.

30. Bryan S. Turner. "Outline of a Theory of Citizenship," Sociology 24, no. 2 (1990): 204.

31. Shafir and Peled, "Citizenship and Stratification," 423.

32. Kimmerling, "Religion, Nationalism and Democracy in Israel," 345.

33. Baruch Kimmerling, "Jurisdiction in an Immigrant-Settler Society," Comparative Political Studies 35, no. 10 (2002): 1122.

34. Ibid.

35. Menahem, 568; Declaration of the Establishment of the State of Israel, May 14, 1948, online: http://www.mfa.gov. il/MFA/Peace\%20Process/Guide\%20to\%20the\%20Peace $\% 20$ Process /Declaration $\% 20$ of $\% 20$ Establishment \%20of\%20State\%20of\%20Israel (accessed 15 June 2010).

36. In the absence of a written constitution, the Basic Law: Human Dignity and Freedom has served as Israel's constitutional Bill of Rights since 1992.

37. Nur Masalha, Is Israel the State of All Its Citizens and "Absentees"? (Haifa, Israel: Galilee Center for Social Research, 1993), 31.

38. Ibid.

39. "New Legal Developments: The New Israeli Government Launches a Flood of Legislation in Violation of the Rights of Palestinian Arab Citizens of Israel," Adalah - The Legal Center for Arab Minority Rights in Israel and The Arab Association for Human Rights (HRA), (4 June 2009), online: http://www.adalah.org/newsletter/eng/jun09/Adalah _HRA_Briefing_note_FINAL_4.6.09.pdf (accessed November 6, 2009).

40. Ibid.

41. See Sammy Smooha, "The Model of Ethnic Democracy: Israel as a Jewish and Democratic State," Nations and Nationalism 8, no. 4 (2002): 423-431; and Yoav Peled, "Ethnic Democracy and the Legal Construction of Citizenship: Arab Citizens of the Jewish State," American Political Science Review 86, no. 2 (1992): 432-443.

42. Oren Yiftachel, "The Shrinking Space of Citizenship: Ethnocratic Politics in Israel," Middle East Research Institute for Palestine 12, no. 5 (2002): 14.

43. Ibid. 
44. Soysal, 109

45. Jeffrey C. Isaac, "A New Guarantee on Earth: Hannah Arendt on Human Dignity and the Politics of Human Rights," American Political Science Review 90, no. 1 (1996): 63.

46. Mark B. Salter, "When the Exception Becomes the Rule: Borders, Sovereignty, and Citizenship," Citizenship Studies 12, no. 4. (2008): 365.

47. Ibid., 366

48. Ibid.

49. Giorgio Agamben, Homo Sacer: Sovereign Power and Bare Life (Stanford: Stanford University Press: 1998).

50. Ibid., 369.

51. Oren Yiftachel, "Ethnocracy: The politics of Judaizing Israel/Palestine," Constellations 6, no. 3 (1999): 384.

52. Merrill A. McPeak, "Israel: Borders and Security," Foreign Affairs, April 1976.
53. Salter, 372.

54. Ibid., 375.

Shourideh C. Molavi (BA, University of Toronto; MA, York University), has worked for the past five years with numerous Palestinian-Arab civil society organizations located in Gaza City, the West Bank, and inside Israel proper. Her most recent post was at MADA al-Carmel-the Arab Center for Applied Social Research, an independent research institute located in Haifa, Israel. MADA served as the institutional base and intellectual climate whereby Molavi was able to study the needs and collective future of the Palestinian-Arab community in Israel. Her academic and political interests concern issues of state-minority relations, democratic citizenship, and human rights, among others. 